Transactions of the royal society of Tropical Medicine and hygiene, Vol. 72, No. 3, 1978

\title{
Congenital Chagas's disease in an urban population: investigation of infected twins
}

\author{
Rodney HoFf and KenNeth E. MotT \\ Department of Tropical Public Health, Harvard School of Public Health, Boston, Massachusetts 02115* \\ Maria Lucila MilanesI \\ Department of Preventive Medicine, Faculty of Medicine, Federal University of Bahia (UFBa) Salvador, \\ Bahia, Brazil ${ }^{\star \star}$ \\ ACHILEA Lisboa BittencourT \\ Hospital Martagao Gesteira, Liga Bahiana contra Mortalidade Infantil, Salvador, Bahia, Brazil
}

AND

Helenemarie Schaer Barbosa

Pathology Service, Tsylla Balbino Maternity Hospital (Prof. fose Maria Magalhaes Neto, Diretor) Salvador, Bahia, Brazil

\begin{abstract}
Summary
In the Nordeste de Amaralina suburb of Salvador, Bahia, Brazil, 47 of 285 pregnant women surveyed had complement fixing antibodies to Trypanosoma cruzi. At delivery T. cruzi was detected in one of 17 placentas from the sero-positive women. The offspring of this case were premature twins and $T$. cruzi was detected in the peripheral blood of each before death. At autopsy the gastro-intestinal tract and urinary bladder of both were severely affected. Immunofluorescence tests on cord sera, including the single case with $T$. cruzi in the placenta, were negative for IgM antibodies to T. cruzi. The mother of the infected twins and three of her living children, who were born and have resided in the city, were also infected with T. cruzi. Although the children had visited an area endemic for Chagas's disease for short periods, the mode of transmission in this family may have been transplacental. The value of the immunofluorescence test in the diagnosis of congenital Chagas's disease is discussed.
\end{abstract}

\section{Introduction}

That congenital transmission of Trypanosoma cruzi might occur was suggested by CHAGAS in 1909 and was confirmed 40 years later by DAO (1949). Since then only about 100 cases have been described in the Latin American literature. The clinical and pathological features of congenital Chagas's disease have been reviewed by HowARD (1976) and BiTteNCOURT (1976 $\mathrm{a}$ and b). However, the public health importance of congenital Chagas's disease remains to be established. Therefore we initiated, in an urban area believed to be free of triatomine vectors, a prospective investigation on the risks for the foetus and for infants born of mothers with serological evidence of infection with $T$. cruzi. In this study we tried several methods for detecting congenital infection with $T$. cruzi.
Clinical, pathological and epidemiological studies on twins with congenital Chagas's disease are described.

\section{Population and Methods}

The study was done in the Nordeste de Amaralina district of Salvador, Bahia, Brazil in 1975 and 1976. The district has a population of 51,000 inhabitants, most of whom are poor and have recently immigrated to Salvador from the interior of the state. Settlement of this district began about ten years ago. The majority of the houses were of brick and cement construction; some were temporary with walls constructed with sticks and mud. Triatomine vectors were not observed in a recent house-tohouse census in this community.

The study population consisted of 960 pregnant women whose children's nutritional status was being followed through infancy by one of us (MLM). Sera were obtained from 285 women during the sixth month of pregnancy and were examined by the complement fixation test for Chagas's disease (Mort et al., 1976). Arrangements were made for collection of placentas of seropositive mothers at delivery. Blood was collected from the foetal side of the placenta with a syringe; wet films were examined directly for parasites; $0.5 \mathrm{ml}$ of heparinized blood was inoculated into each of 2 NNN cultures (PAN, 1968) and the remainder of the blood was allowed to clot and the serum removed. The placentas were then fixed

\footnotetext{
* The Havard component is supported by a grant from the Wellcome Trust, under the direction of Dr. Thomas H. Weller, and its collaborative activitics in Brazil are under the acgis of the Pan American Health Organization.

$\star \star$ Field work in Nordeste de Amaralina is supported by grants from the Ford Foundation and the Rockefeller Foundation.
} 
Table I-Examination of placentas for $T$. cruzi and IFAT titres on maternal and cord serum

\begin{tabular}{ccccc}
\hline $\begin{array}{c}\text { Mother's } \\
\text { Number }\end{array}$ & $\begin{array}{c}\text { Placental } \\
\text { exam for } \\
T . \text { cruzi }\end{array}$ & $\begin{array}{c}\text { Mother's } \\
\text { IgG-IFAT } \\
\text { titre }^{+}\end{array}$ & \begin{tabular}{c} 
Cord Serum IFAT \\
\cline { 4 - 4 } titre $^{+}$
\end{tabular} & $\begin{array}{c}\text { IgM } \\
\text { titre }^{+}\end{array}$ \\
\hline 1 & neg & 512 & 256 & $<16$ \\
2 & neg & 256 & 256 & $<16$ \\
3 & neg & 256 & 256 & $<16$ \\
$4^{\star \star}$ & neg & 256 & 256 & $<16$ \\
5 & neg & 512 & 512 & $<16$ \\
6 & neg & 256 & 256 & $<16$ \\
7 & neg & 64 & $<16$ & $<16$ \\
8 & neg & 64 & 64 & $<16$ \\
$9^{\star \star}$ & pos & 256 & 256 & $<16$ \\
10 & neg & 1024 & 1024 & $<16$ \\
11 & neg & 512 & 256 & 256 \\
12 & neg & 256 & & 16 \\
\hline
\end{tabular}

$\star$ At 6 th month of pregnancy. Significant titre considered to be 64 .

** Mothers had twin births.

${ }^{+}$Expressed as reciprocal.

Table II-Follow-up examination of 6 infants of sero-positive mothers: Comparison of cord serum IFAT titres with infant serum titres at various ages

\begin{tabular}{|c|c|c|c|c|c|c|}
\hline \multirow{2}{*}{$\begin{array}{l}\text { Mother's } \\
\text { Number }\end{array}$} & \multicolumn{2}{|c|}{ Cord blood* } & \multicolumn{4}{|c|}{ Infant blood } \\
\hline & IgG-IFAT $^{+}$ & IgM-IFAT $^{+}$ & Age (days) & Parasitaemia & IgG-IFAT $^{+}$ & IgM-IFAT $^{+}$ \\
\hline 1 & 256 & $<16$ & 102 & neg & 64 & $<16$ \\
\hline 2 & 256 & $<16$ & 45 & neg & 64 & $<16$ \\
\hline 4 & 256 & $<16$ & 28 & neg & 256 & $<16$ \\
\hline & & & 28 & neg & 64 & $<16$ \\
\hline 5 & 512 & $<16$ & 21 & neg & 256 & $<16$ \\
\hline 6 & 256 & $<16$ & 43 & neg & 64 & $<16$ \\
\hline
\end{tabular}

* Placentas were negative for $T$. cruzi.

+ Fxpressed as reciprocal.

in $10 \%$ formalin for histopathological examination (BITTENCOURT et al., 1972).

The cord serum and the mother's serum were tested for antibodies to $T$. cruzi by the indirect immunofluorescence antibody test (IFAT) (CAMARGo, 1974) using conjugated anti-IgG and anti-IgM (Cappel Laboratories, Downington, Pa.). In addition, blood from six infants of sero-positive mothers was examined for parasites and by IFAT at intervals varying from 21 days to 102 days after delivery.

\section{Results}

Of the 285 matcrnal scrum samples, $47(16 \cdot 5 \%)$ were positive with Chagasic CF titres of $\geq 1: 4$. Placentas were obtained from 17 of the 47 women $(36 \cdot 2 \%)$. All procedures were completed on the 12 placentas received within a few hours of delivery; only direct blood examination and histological examination were performed on five placentas refrigerated for more than a day before reaching the laboratory. T. cruzi was detected in one of the $17(5 \cdot 8 \%)$ placentas by direct film examination, by culture, and by histological examination. Titres for T. cruzi antibodies by IgG-IFAT on cord sera reflected maternal titres while the IgM-IFA tests were negative on all cord sera including that of the placenta positive for T. cruzi (Table I). Six infants whose placentas were negative for $T$. cruzi were followed; the wet blood films and the IgM-IFA test remained negative (Table II). The IgG-IFA test was positive for up to 102 days, although with increasing age titres declined.

The offspring of the case with $T$. cruzi in the placenta were premature dizygotic twins. When examined on the second day of life the male twin weighed $1,170 \mathrm{~g}$ and the female $1,200 \mathrm{~g}$. At this time $T$. cruzi trypomastigotes werc detected in direct films of peripheral blood from the female but not from the male. By five days of age, diarrhoea and dehydration appeared and T. cruzi was demonstrated in the peripheral blood of both. Despite antibiotic therapy and intravenous fluids, the female infant died on the sixth day and the male on the seventh day.

At autopsy the neonates were emaciated and exhibited petechiae. Gross and microscopic findings were similar in both. There was moderate hepato- 
Table III-Investigation of the family with congenital $T$. cruzi infection

\begin{tabular}{|c|c|c|c|c|c|}
\hline $\begin{array}{l}\text { Family } \\
\text { member }\end{array}$ & $\begin{array}{l}\text { Present } \\
\text { age }\end{array}$ & $\underset{\text { titre }}{\mathrm{CF}}$ & $\begin{array}{l}\text { IFAT } \\
\text { titre }\end{array}$ & $\begin{array}{c}\text { Xeno- } \\
\text { diagnosis }\end{array}$ & $\begin{array}{c}\text { Blood } \\
\text { culture }\end{array}$ \\
\hline Mother no. 9 & 33 & 32 & 256 & pos & pos \\
\hline Pregnancy 1 & 17 & $<4$ & $<16$ & neg & neg \\
\hline Pregnancy 2 & 14 & 8 & 16 & not done & pos \\
\hline Pregnancy 3 & \multicolumn{5}{|c|}{ Stillborn 13 years ago } \\
\hline Pregnancy 4 & 12 & 8 & 256 & neg & pos \\
\hline Pregnancy 5 & 10 & 16 & 256 & pos & neg \\
\hline Pregnancy 6 & 6 & $<4$ & 16 & neg & neg \\
\hline Present pregnancy: & \multicolumn{5}{|c|}{ twins congenitally infected with $T$. cruzi } \\
\hline
\end{tabular}

* Titre of 8 considered to be significant.

megaly and an involuted thymus, but heart size was normal. Microscopically, rare foci of mononuclear cell infiltrates were present in the brain and occasional areas of focal myocardial oedema with discrete mononuclear infiltration were noted in the heart. The thymus was severely depleted of lymphocytes. Inflammation was most severe in the urinary bladder and the gastro-intestinal tract where $T$. cruzi was observed in muscle fibres and histiocytes.

The placenta which was fused, biamniotic and bichorionic, weighed $510 \mathrm{~g}$ and was grossly normal. Microscopically, rare foci of villous and perivillous chronic granulomatous inflammation were observed. Parasitized cells were present in the chorionic plate, in villi and in the extra-placental amnion which also had zones of epithelial necrosis. Parasitized macrophages were also observed in Wharton's jelly of the umbilical cord.

Familial Investigation: The 33-year-old mother of the infected twins had lived in a typical mud-stick house in an area endemic for Chagas's disease in the interior of Bahia until she moved to Salvador at age 13. Thereafter she worked as a resident domestic maid in the city. From 1959 to 1966 she lived in a mud-stick house in an area of Salvador where domestic triatomine vectors were present in 1965 (DA Silva, 1966). However, she and her family did not recall observing triatomines or being bitten during this period. For the last nine years she has lived in the Nordeste de Amaralina, an area considered to be free of triatomines, and a search of her house revealed no evidence of triatomine infestation. During her residence in Salvador she and her family travelled on several occasions to her former home in the interior, staying for several days but they did not recall any contact with triatomines. She had never received a blood transfusion.

The mother had six previous pregnancies; there are five living children, all of whom were born in Salvador. Her third pregnancy terminated with a premature stillborn child in 1966. After the third pregnancy she developed shortness of breath which became severe during subsequent pregnancies. Her ECG indicated complete right bundle branch block. The heart size was normal. The mother and three of her five living children were seropositive and $T$. cruzi was detected by culture or xenodiagnosis (Table III). The infected children had no signs or symptoms of acute or chronic Chagas's disease.

\section{Discussion}

Because our numbers are small, it is not possible to estimate the rate of transplacental transmission of $T$. cruzi in chronically infected mothers. Nevertheless, demonstration of parasites in one of 17 placentas suggests that the problem may be more common than assumed. In a similar study, SzARFMAN et al. (1976) encountered four cases of congenital $T$. cruzi infection among 566 newborn $(0.71 \%)$ of sero-positive mothers in urban Buenos Aires.

In our hands the IgM-IFA test on cord sera was negative, including the case with congenital infection. That these data do not reflect a deficiency in the test is suggested by the fact that examination of the "positive" cord serum using anti-IgM conjugates from several commercial sources also gave negative results. Further, in our laboratory this test was positive with high titres on examination of sera from all of 13 individuals with acute Chagas's disease (HOFF, unpublished data). STAGNO \& HuRTado (1972) suggested that the IgM-IFA test is particularly useful for diagnosis of congenital infection in newborns when parasitemia is subpatent. However, SZARFMAN et al. (1976) observed negative IgM-IFA tests in two of six newborns with congenital infection. Thus, while a positive IgM-IFA test may help confirm the diagnosis of congenital infection, a negative result does not exclude it. For this reason the IgM-IFA test should be used in conjunction with methods to demonstrate the parasites. Negative IgM-IFA tests have also been observed in congenital toxoplasmosis (REMINGTON \& Desmonts, 1973). The apparent lack of a specific, foetal anti-T. cruzi IgM response in this case could be due to the effect of overwhelming infection on an immature immune system or the specific suppression of the IgM response by the presence of high levels of maternal IgM antibody (ARAUJO \& REMINGTON, 1976). Alternatively, the negative IgM-IFAT could be the consequence of foetal IgM antibodies forming a complex with excess $T$. cruzi antigen in vivo. 
T. cruzi was detected in the mother and in three of her five offspring. Infection in three living children, who were born and had resided in the city, was unexpected. It is not possible, in the living children, to rule out triatomine transmission, because vectors have been reported in scattered areas of Salvador as recently as 1965 (DA SILVA, 1966) and because these children had briefly visited endemic areas in the interior. On the other hand, habitual congenital transmission of T. cruzi in successive pregnancies has been reported in Brazil (BITTENCOURT \& GoMes, 1967) and in Chile (RUBIo in HowaRD, 1976) and is a possible explanation for these cases. To date, studies of congenital $T$. cruzi infection have been largely limited to symptomatic cases encountered in hospitals. It would be important to know if asymptomatic forms of the infection exist as is the case with cytomegalovirus infection (WELLER, 1971; HANSHAW, 1969). Serological and parasitological studies of children of chronically infected mothers who live in triatomine-free urban areas, such as described in this paper, may help to elucidate the natural history of congenital $T$. cruzi infection.

\section{References}

Araujo, F. G. \& Remington, J. S. (1975). IgG antibody suppression of the IgM antibody response to Toxoplasma gondii in newborn rabbits. Fournal of Immunology, 115, 335-338.

Bittencourt, A. L. (1976a). Pathologic aspects of congenital transmission of T. cruzi. In: American Trypanosomiasis Research, PAHO Scientific Publication, No. 318, pp. 216-220.

Bittencourt, A. L. (1976b). Congenital Chagas' Disease. American Fournal of Diseases of Children, 130, 97-103.

Bittencourt, A. L., Barbosa, H. S., Rocha, T., Sodre, I. \& Sodre, A. (1972). Incidencia da transmissao congenita da doenca de Chagas em partos prematuros na Maternidade Tsylla Balbino (Salvador, Bahia). Revista do Instituto de Medicina Tropical de São Paulo, 14, 131-134.

Bittencourt, A. L. \& Gomes, M. C. (1967). Gestaçoes sucessivas de uma paciente chagasica com ocorrencia de casos de transmissao congenita da doença. Gazeta Medica da Bahia, 67, 166-172.

Camargo, M. E. \& Neto, V. A. (1974). AntiTrypanosoma cruzi IgM antibodies as serological evidence of recent infection. Revista do Instituto de Medicina Tropical de São Paulo, 16, 200-202.
Dao, L. (1949). Otros casos de enfermedad de Chagas en el Estado Guárico (Venezuela). Formas agudas e crónicas. Observación sobre enfermedad de Chagas congénita. Revista Policlinica Caracas, 18, 17-22.

Hanshaw, J. B. (1969). Congenital cytomegalovirus infection: Laboratory methods of detection. Fournal of Pediatrics, 75, 1179-1185.

Howard, J. E. (1976). Clinical aspects of congenital Chagas' Disease. In: American Trypanosomiasis Research, PAHO Scientific Publication, No. 318, pp. 212-215.

Mott, K. E., Lehman, J. S., Hoff, R., Morrow, R. H. Muniz, T. M., Sherlock, I., Draper, C. C., Pugliese, C. \& Guimaraes, A. C. (1976). The epidemiology and household distribution of seroreactivity to Trypanosoma cruzi in a rural community in Northeast Brazil. American fournal of Tropical Medicine and Hygiene, 25, 552-562.

Pan, C. (1968). Cultivation of the leishmaniform stage of Trypanosoma cruzi in cell-free media at different temperatures. American fournal of Tropical Medicine and Hygiene, 17, 823-832.

Remington, J. S. \& Desmonts, G. (1973). Congenital toxoplasmosis: variability in the IgM fluorescent antibody response and some pitfalls in diagnosis. fournal of Pediatrics, 83, 27-30.

da Silva, G. R. (1966). Doença de Chagas em familias de duas areas restritas da cidade de Salvador, Bahia. Thesis, Faculdade de Medicina da Universidade de São Paulo.

Stagno, S. \& Hurtado, R. (1972). Enfermedad de Chagas' congenita. Estudio immunologico y diagnostico mediante immunofluorescencia con anti-IgM. Boletin Chileno de Parasitologia, 27, 20-27.

Szarfman, A., Cossio, P. M., Arana, R. M., Urman, J., Kreutzer, E., Laguens, R. P., Segal, A. \& Coarasa, L. (1975). Immunological and immunopathologic studies in congenital Chagas' disease. Clinical Immunology and Immunopathology, 4, 489-499.

Weller, T. H. (1971). The cytomegaloviruses: ubiquitous agents with protean clinical manifestations. New England fournal of Medicine, 285, 203-214, 267-274.

Accepted for publication 18th November, 1977. 